\title{
マングローブ林による消波と侵食防止の 効果評価法
}

\author{
山本 吉道 1 Puangpet RATTANARAMA ${ }^{2}$ - Arjong NOPMUENG ${ }^{3}$ \\ 1フェロー会員 東海大学教授 工学部土木工学科（テ259-1292 神奈川県平塚市北金目4-1-1） \\ E-mail:yo-yamamo@tokai-u.jp \\ 2モンクット王工科大学ラカバン校准教授＼cjkstart建築学部（Ladkrabang, Bangkok, Thailand) \\ E-mail:ramaratt@yahoo.com \\ 3 東海大学大学院学生 工学研究科土木工学専攻（广259-1292 神奈川県平塚市北金目4-1-1） \\ E-mail:sakurazaki_blm@hotmail.com
}

\begin{abstract}
タイ国には，マングローブを大量伐採した結果，深刻な侵食が生じている海岸が各所にある。このよう な海岸では, 離岸堤等の侵食対策構造物が設置されつつあるが, マングローブ林の再生こそ, 自然的で永 続性のある工法と考えられる. それゆえ, マングローブの中から, 植林し易く, $7 \cdot 8$ 年で高い消波効果 を期待出来るタイプとして支柱根タイプを選び，これによる消波と侵食防止効果を高い信頼性の基に評価 できる方法を提案する，具体的には，水理模型による消波実験を行い，既往文献の消波データと合わせて， 実用的な消波効果算定図を作成する。次に，水理模型による侵食実験デー夕を用いて海浜地形変化の良好 な再現性を確認した数值予測モデルを用いて, 有効なマングローブ林の所要幅を求める.
\end{abstract}

Key Words : mangrove woods, wave dissipation, coastal erosion prevention, effect evaluation method

\section{1.はじめに}

タイ国では，薪・炭材として利用するためや，海老養 殖池造成のために，マングローブを大量伐採した結果， 深刻な海岸侵食が続いている. マングローブ林が存在す る海岸は粘土質であったが，粘土分が流出した結果，シ ルト質砂浜になっている場合が多い，そして，侵食対策 工として，コンクリートブロックや捨石による離岸堤や 突堤も存在するが，顕著な沈下が生じるため，土砂を詰 めたジオテキスタイル袋による離岸堤や竹製群杭の消波 堤も建設されており, Rattanaramaら ${ }^{1)}$ は, これらに十分 な侵食防止効果を期待できるが，これらは恒久的な対策 工でないことを言っている，そして，マングローブ林の 再生こそ，自然的で永続性のある工法と考えられるため, Nopmueng ${ }^{2)}$ は, タイ国での現地調査から，マングロー ブの中で，植林し易く， $7 \cdot 8$ 年で高い消波効果を期待 出来るタイプとして支柱根（複数の根がタコの足のよう に伸びて幹を支える）タイプを選び，既往文献より消波 効果算定図を作成し，これを用いた侵食防止効果の数值 計算から, 有効なマングローブ林の所要幅について検討 したが，算定図の精度が不十分であった.

本研究では，マングローブ林による消波と侵食防止効 果について，信頼性の高い評価方法を提案する.

\section{2. マングローブによる消波効果}

\section{(1) 消波効果の水理模型実験}

Nopmueng $ら^{2)}$ は, Bao $^{3)}$, Brinkman ${ }^{4)}$, Fatimah $ら^{5)}$,

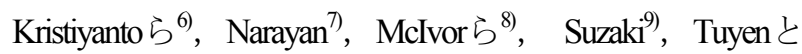
Hung ${ }^{10)}$ の 8つの既往研究から, 支柱根タイプのマング ローブ林に対する波の透過比（透過波高／入射波高） に関するデータを集め, マングローブ林の密集度 $\left(D\right.$ : 地面 $1 \mathrm{~m}^{2}$ 当りの主幹の本数) 別に, 林の幅と透 過比の関係図を作成したが，林の幅に対する波長の影 響が考慮されていないため, その精度は高くない. そ れゆえ，この影響を確認するために，また，波が支柱 根の中央部に作用寸る場合と上部に作用寸る場合の違 いも確認するために, 以下の実験を実施した.

Nopmueng ら $^{2)}$ が実施した現地調查成果を基に, 図-1 に示す支柱根タイプの典型的なマングローブ模型を基 本的に同寸法で必要個数造った（ただし，手作りであ るため, 形状は微妙に異なる. また, 二次元水路に千 鳥に置く必要性から, 左右半分に割ったタイプもあ る）。そして，図-2及び図-3に示寸ように，二次元水 路に $10 \mathrm{~cm}$ 厚の砂質ローム層（中央粒径 $0.2 \mathrm{~mm}$, 均等 係数 20）を敷いて，マングローブ模型を固定すること で，小規模な林（模型縮尺1/10）を再現した. 


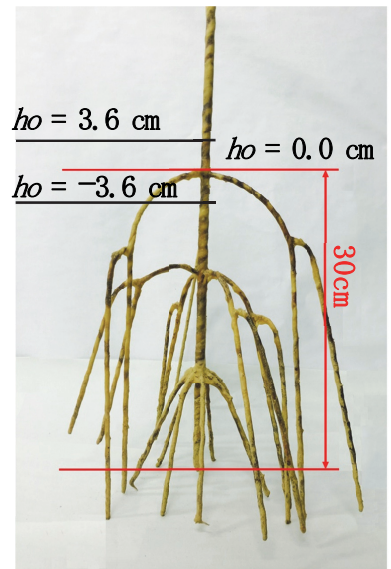

図-1

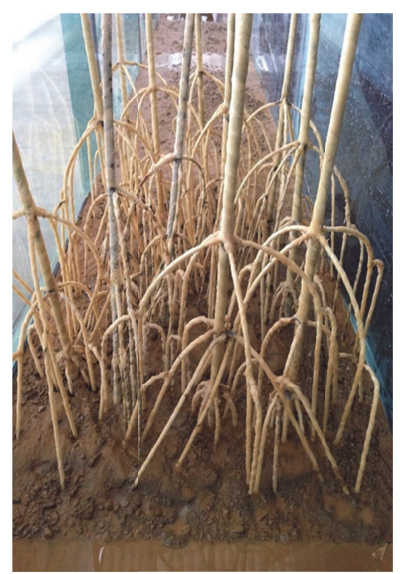

図-2 マングローブ設置例 (実験スケールで $D=0.5$ の場合)

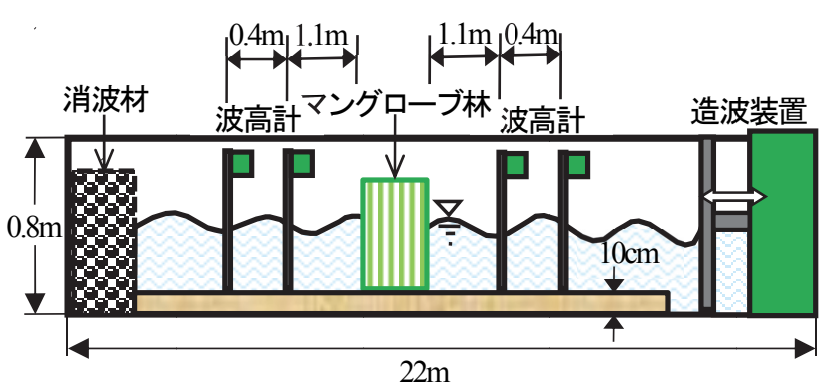

図-3 消波模型実験装置の説明図
そして，有義波高（Hi） $1.8 \mathrm{~m}$ （模型実験で $18 \mathrm{~cm}$ ) で 有義周期 4 秒（模型実験で1.25秒）の不規則波（タイ国 にて典型的な高波）を入射させて，図-1に示す支柱根 の上端から模型上で $3.6 \mathrm{~cm}$ 下側に水面 $(h o / H i=-0.2)$ がある場合と， $3.6 \mathrm{~cm}$ 上側に水面 $(h o / H i=0.2)$ がある 場合について，木の密集度（D）と林幅／波長（林の 直前面）を変えて消波実験を実施した.

ただし，図-3に示されるように，模型地層上で模型 林の前後に二基づつの波高計を配置することで，水深 が右側造波部と違うことによる影響を排除し，入反射 分離も実施した。また，波高測定間での模型地層の底 面摩擦の影響は，Bretschneider とReidの式 ${ }^{11)}$ から波高減 衰係数が 0.99以上となるので無視した.さらに，波高 を変えることによる波形勾配の違いが透過比に及ぼす 影響も, Suzuki $i^{99}$ の検討よると小さいので無視した.

本水理模型実験の測定データを消波効果についてまと めると，図-4に示すようになった，本図は，相対的水深 (ho/Hi) が浅くなるほど, また，木の密集度（模型上 では $0.01 \mathrm{~m}^{2}$ 当りの本数）と林幅／波長（無次元林幅）が 大きくなるほど，波の透過比が小さくなることを示す.

\section{（2）波の透過比算定図の改良}

図-4から読取れるho/Hi=0.0に対する透過比を基にし て, 前述の 8 つ既往研究から得られる支柱根タイプ のマングローブ林に対する波の透過比を，木の密集度

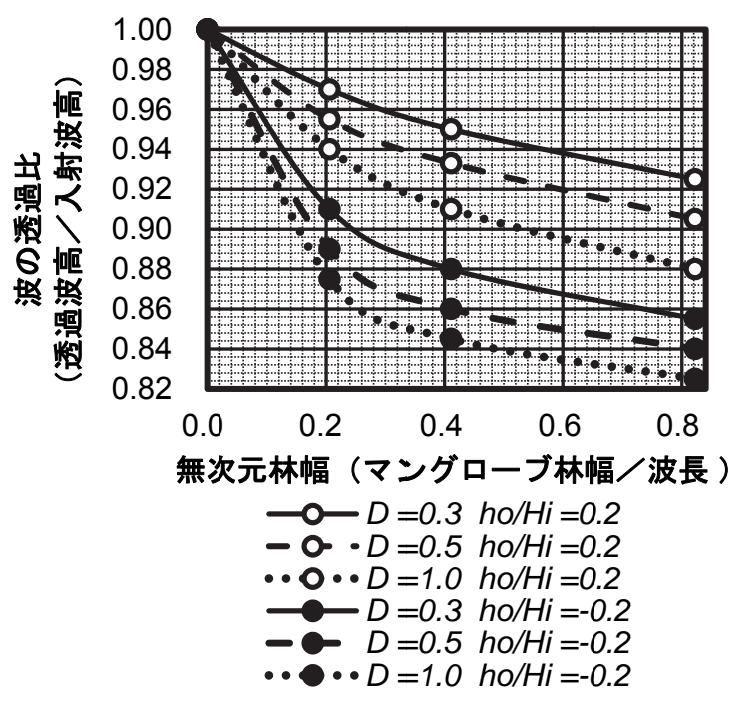

図-4 水理模型実験データによる波の透過比 (Dは $1 \mathrm{~m}^{2}$ 当り の木の本数, ho/Hi は図-1 に示亦水面高と入射波高の比)

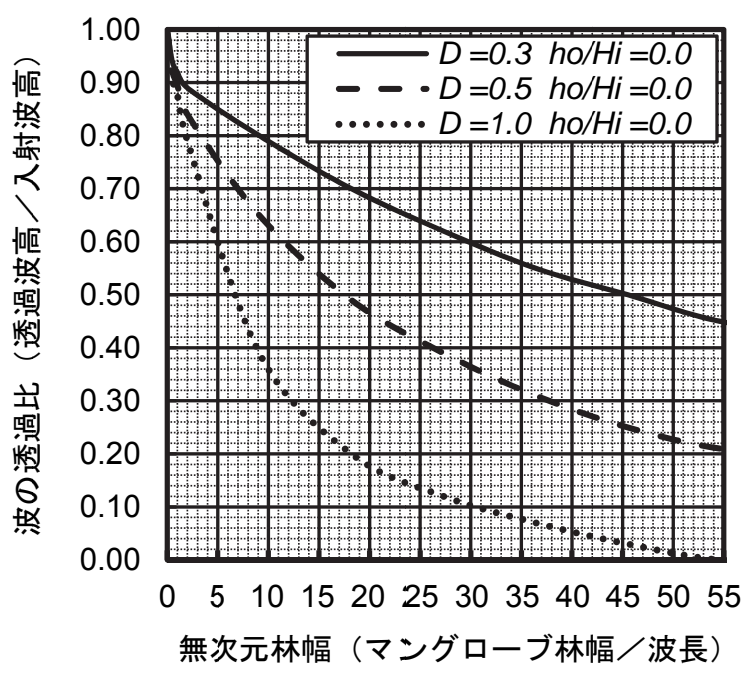

図-5 既往文献データと図-4の平均值による波の透過比 $(D=0.3$ は自然林での, $D=1$ は人工林での最頻度值 $)$

（D）と林幅／波長を変数に整理し直し，図-5に示す ように，密集度の3タイプ毎に平均化して消波効果算定 図を作成した. Alongi $^{12)}$ は複数の論文調査から，波の周 期 (波長) の違いが林幅と透過比の関係に大きな影響 を及ぼすことを指摘し，密集度が高く周期が 2 ～秒の 場合に，透過波高は林幅 $50 \mathrm{~m}$ 程度で半減するのに対し て，普通の密集度で周期が8秒の場合には，半減するた めに $400 \mathrm{~m}$ 程度必要なことを示している. マングローブ 林の水深として標準的な0.5〜2.0mを想定すれば，この 記述と図-5の曲線は良く整合している.

ここで，相対的水深（ho/Hi） をゼロで整理した理由 は，図-1に示す相対的水深が明確に分かる既往文献が 少ないこととと, 後述する地形変化の検討期間となる 一時化の間の潮位変動が大きい場合が普通であるから である．なお，実際の平均水面は根の上端より低いの が普通であり，この条件（ho/Hi=0.0）は安全側になる. 


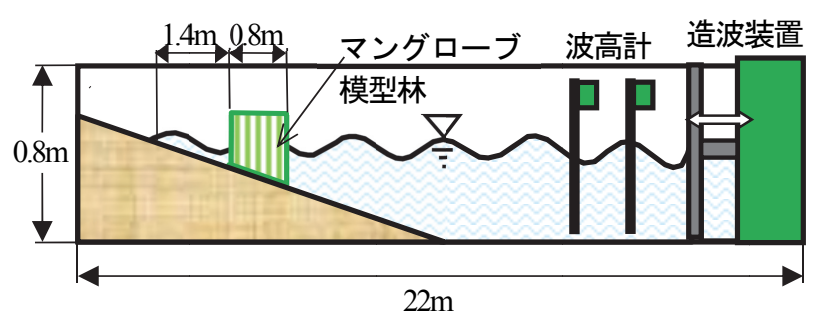

図-6 侵食防止実験装置の説明図

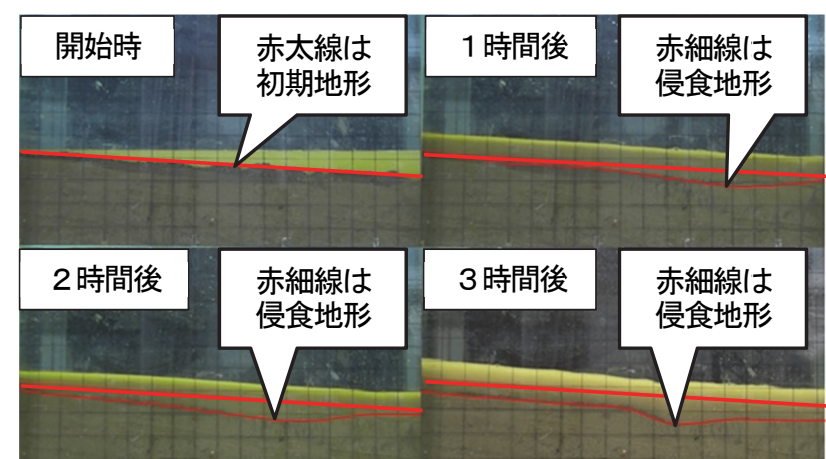

図-7 マングローブ林無しの実験での汀線付近の侵食状況

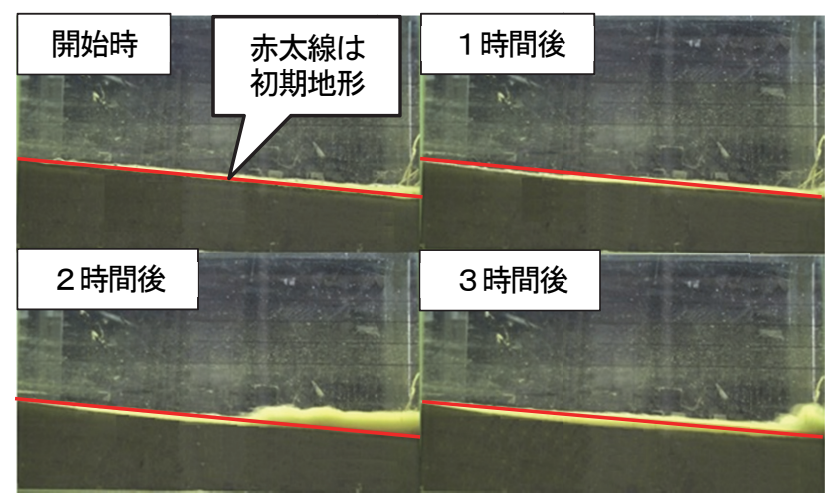

図-8 マングローブ林有りの実験での汀線付近の侵食状況

\section{3. マングローブによる侵食防止効果}

\section{(1) 侵食防止効果の水理模型実験}

Rattanarama $ら^{1)}$ やNopmueng $ら^{2)}$ は，対策工前面の洗掘 に対して高い再現精度を有していることを確認済みの $\mathrm{Ca} 5^{13)}$ の平面二次元地形変化数值モデルを用いて，侵 食対策工による防止効果を評価した．しかし，この数 值モデルによるマングローブ林陸側の波高・侵食低減 の再現精度の確認は十分でない，それゆえ，図-6に示 す二次元水路に前述の砂質ロームを用いて侵食の生じ 易い勾配 $1 / 20$ の海浜を造り，汀線近傍に出来る顕著な 侵食区間の直ぐ沖側（汀線から模型上 $1.4 \mathrm{~m}$ 沖側）に模 型林（模型上 $0.01 \mathrm{~m}^{2}$ 当り1本の密集度で幅 $0.8 \mathrm{~m}$ ） が有る

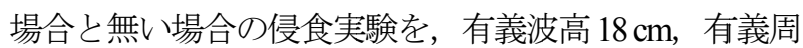
期 $1.2 \sec の$ 不規則波を 3 時間作用させて行った．特に, マングローブ林有りの場合は，岸側侵食量が小さくな り，測定精度が低下寸るため 3 回実施した.

マングローブ林無しの場合の汀線付近の侵食状況を
表-1 侵食の実験測定值と数值計算值との比較

\begin{tabular}{|c|c|c|c|c|c|c|c|}
\hline \multirow{4}{*}{$\begin{array}{c}\text { 作用 } \\
\text { 時間 } \\
\text { (分) }\end{array}$} & \multicolumn{7}{|c|}{ 侵食面積 $\left(\mathrm{cm}^{2}\right)$} \\
\hline & \multicolumn{2}{|c|}{ マングロ一ブ無し } & \multicolumn{5}{|c|}{ マングロ一ブ有り } \\
\hline & \multirow{2}{*}{ 測定値 } & \multirow{2}{*}{ 計算値 } & \multicolumn{4}{|c|}{ 測定值 } & \multirow{2}{*}{$\begin{array}{l}\text { 計 } \\
\text { 算 } \\
\text { 値 }\end{array}$} \\
\hline & & & 1 回 & 2 回 & 3 回 & 平均 & \\
\hline 60 & 43.0 & 70 & 5.7 & 6.8 & 7.1 & 6.5 & 11 \\
\hline 120 & 91.0 & 120 & 7.8 & 9.0 & 8.9 & 8.6 & 22 \\
\hline 180 & 191.5 & 200 & 8.1 & 11.6 & 10.9 & 10.2 & 35 \\
\hline
\end{tabular}

図-7に示寸. 1 時間後の侵食断面積は $43.0 \mathrm{~cm}^{2} ， 2$ 時間

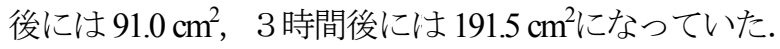
マングローブ林有りの場合の汀線付近の侵食状況の例 を図-8に示す。このケースでの 1 時間後の侵食断面積 は $6.8 \mathrm{~cm}^{2}, 2$ 時間後には $9.0 \mathrm{~cm}^{2}, 3$ 時間後には $11.6 \mathrm{~cm}^{2}$ と大幅に低減していた.

\section{（2）侵食防止効果評価法の精度確認}

前述の侵食実験を $\mathrm{Ca} ら^{13)}$ の数值モデルを用いて再現し た. 本数值モデルでは，流体場を水深方向に積分された Boussinesq 方程式で，砕波によるエネルギー損失を $k-\varepsilon$ 乱流モデルで表し, 底面摩擦も考慮して, 差分法によっ て解かれ，空間差分にはstaggered gridを，時間差分には Crank-Nicolson schemeを用いている。 そして, Caら ${ }^{13)}$ は回 折・屈折・浅水変形，および，遡上運動の再現性能の高 いことを示しているが，マングローブ林による透過波に ついて, Rattanarama ${ }^{1)}$ と同様に透過係数の形で運動 方程式に考慮し，その妥当性を本検討で確認する．また， 入射波について，方向スペクトル密度関数を用いた成分 波の重社合せで不規則性を考慮しているが，側面境界か らの斜め入射が出来ないため, 評価対象海域の両側方に 余分な計算領域が必要である. この側方余裕長が計算範 囲の岸沖距離の $2 / 3$ 以上あれば支障無いことも確認する. マングローブ林無しの場合の計算結果を図-9 に，同 林を両端までの連続施設として設置した場合の計算結果 を図-10 に示す．ここで，両側方を岸沖距離の $2 / 3$ ほど カットして表示しており, 差分格子間隔は $8 \mathrm{~cm}$, 波の 透過比には，図-4の $D=1.0$ で $h o / H i=-0.2$ のグラフ上で, 林幅 $/$ 波長 $=0.8 \mathrm{~m} / 1 \mathrm{~m}=0.8$ に対寸る值 0.8 を, 波の工 ネルギー集中度パラメーター $S_{\max }$ には 25 を用いた。

両図の波高分布の比較から，マングローブ林の陸側近 傍での波高比は $(2.8 \sim 2.9 \mathrm{~cm}) /(3.5 \sim 3.6 \mathrm{~cm})=0.8$ となり, 計算条件值と一致することから，透過波の計算精度の高 いことを確認できた．さらに，水深変化量図において， 汀線の海側近くに集中的に生でる侵食断面積の平均值を 求め, 侵食実験から得られた侵食断面積の実測值と共に 表-1 に整理した. これらの数值を比較すれば，図-11に 示すようになり, 計算值の侵食の方が大きい結果になっ ているが，本図の数值間の相関係数を求めると 0.99 と なり，十分に良い再現精度を得られていると判断できる. 


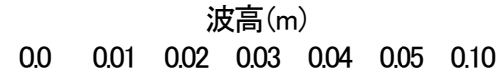

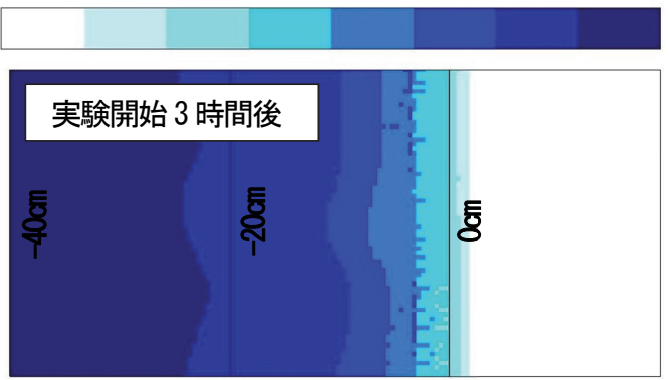

水深変化量 $(\mathrm{m})$

$\begin{array}{lllllll}-0.08 & -0.06 & -0.04 & -0.02 & 0.0 & 0.02 & 0.10\end{array}$
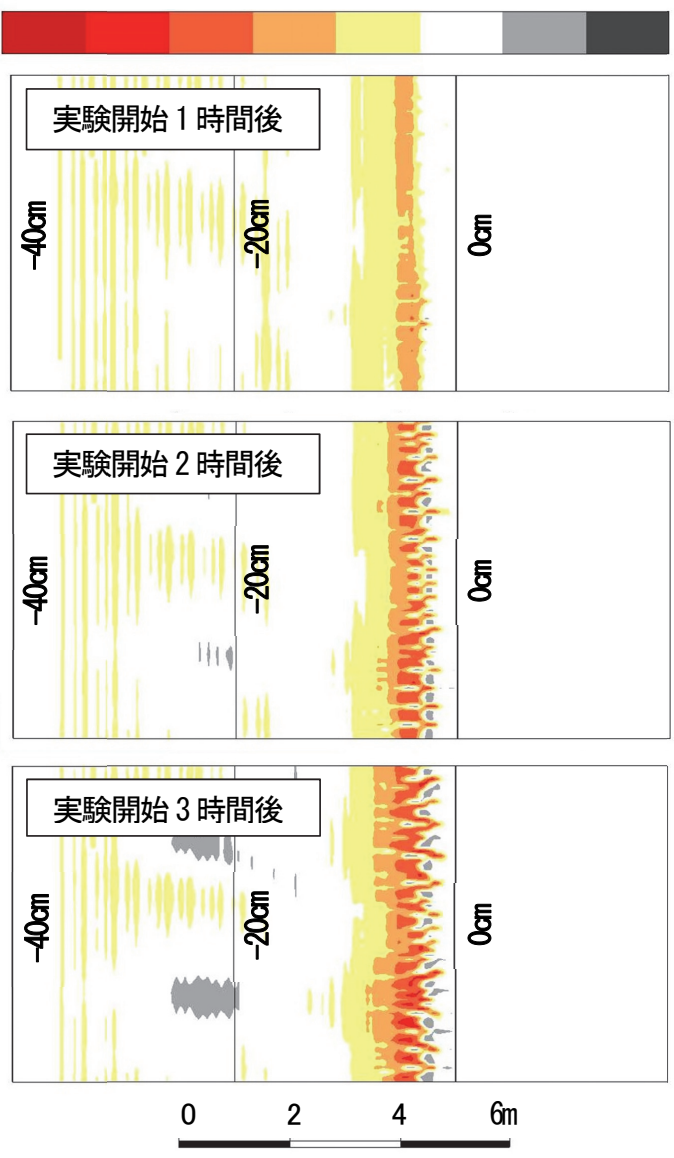

図-9 マングローブ林無しの場合の波高と水深変化量の 数值計算結果（図中の数值は水深コンターの值）

なお，これらの図には波が側方境界から入射されない ことによる影響が及んでいないことが読み取れるので， 側方余裕長は岸沖距離の $2 / 3$ で十分であると言える.

また，マングローブ林有りの侵食断面積の計算值が実 測值より大きくなった原因として，実験波高の目測の方 が計算值より小さかった印象があること，および，侵食 実験のマングローブ林の平均水深が消波実験の同林の水 深に比べて相当に浅いことから，マングローブ林による 消波効果を過小評価していた可能性と, 底面摩擦係数を 標準の 0.01 にしていたのでは，底面摩擦力を過小評価 していた可能性を指摘できる。
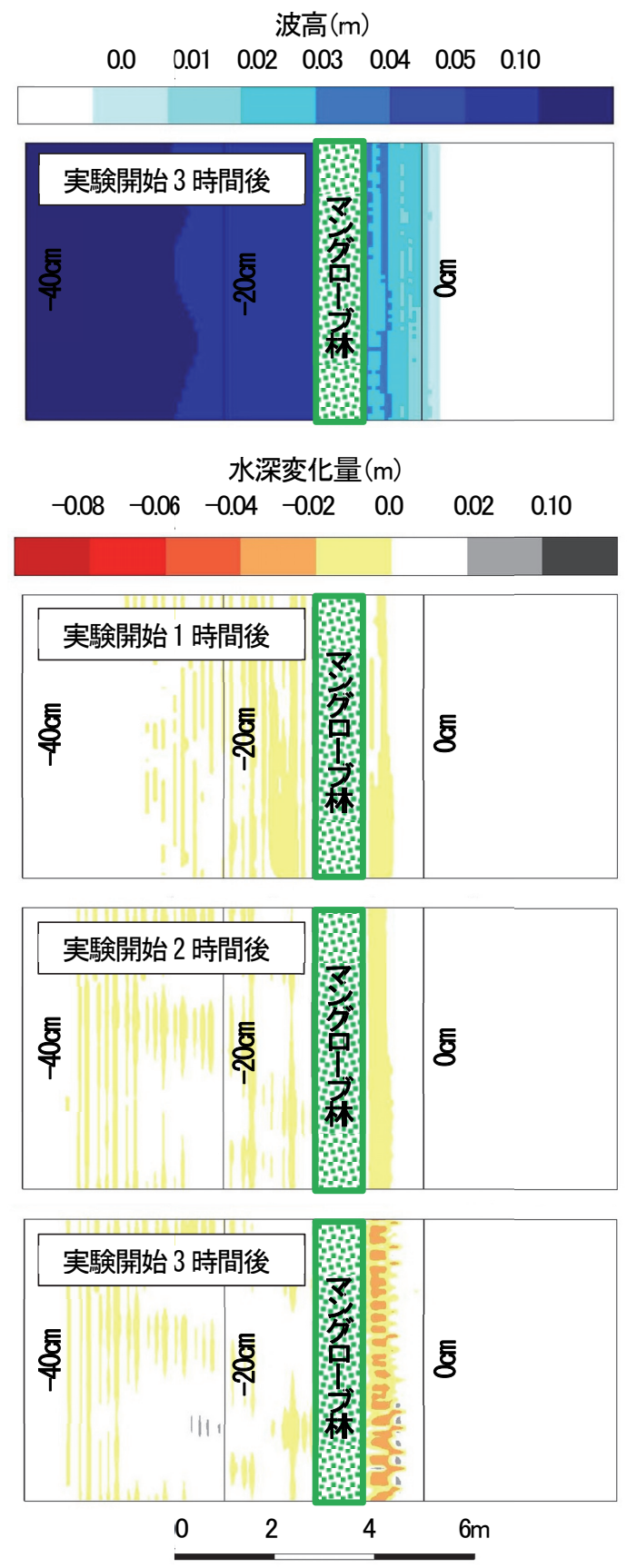

図-10 マングローブ林有りの場合の波高と水深変化量の 数值計算結果 (図中の数值は水深コンターの值)

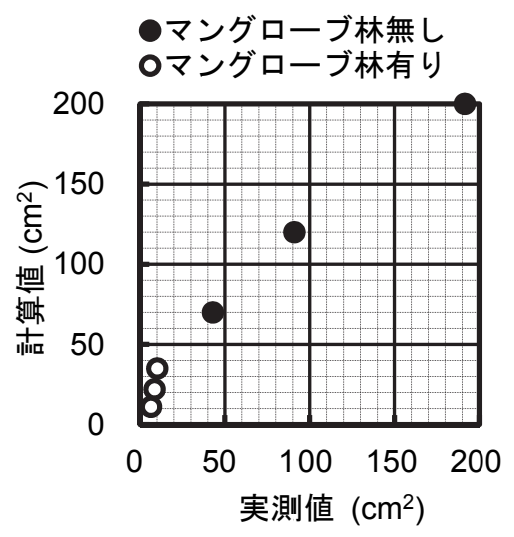

図-11 侵食断面積の実験実測值と数值計算值との相関 


\section{(3) マングローブ林による侵食防止効果の評価}

支柱根タイプのマングローブ林による侵食防止効果 とRattanarama ${ }^{1)}$ の離岸堤による防止効果とを比較する ため，以下に示寸条件て侵食予測計算を行った：

(a) 図-5の算定図と $\mathrm{Ca} ら^{133}$ の数值モデルによる評価法は, 前節の検討からマングローブによる侵食防止効果を過小 評価する可能性を否定できないが，これは安全側の結果 を得られることを意味するので，この組合せで評価する， なお，内山 ${ }^{14)}$ などが指摘しているように，典型的な干潟 での地形変化に対して, 波と海浜流による機械的作用が 及ぼす影響は限られている。 しかし，タイ湾奥のシルト 質海岸では，マングローブ林伐採によって波当たりが強 くなった結果, 侵食が進み, 粘土分が流失して砂質分が 相対的に増えて，海岸地形変化を波と海浜流による機械 的作用で説明できる場合が増えている. Rattanaramaら も $\mathrm{Ca} ら^{13)}$ の数值モデルで離岸堤陸側の侵食防止効果を良 好に再現出来たことを報告している.

(b) 検討のためのモデル海岸には，タイ湾奥で見かける

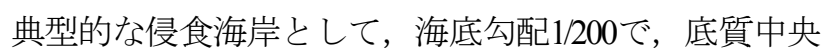
粒径0.1 mmのシルト質海岸を設定し, 差分計算での格子 間隔は $1.25 \mathrm{~m}$ とする.

(c) 外力データには, タイ国政府から入手した 2005 年 3 月 ～2006年11月の波観測値と2011年1月～12月の波推算值 を一日平均值で整理したデータから, 時化時外力として 平均有義波高 $1.25 \mathrm{~m}$ ，平均有義周期 $3.7 \mathrm{sec}$ の波を 3 日連続 作用させる.この全波エネルギーは 1 年間の高波時波エ ネルギーに相当する．また，波のS $S_{\max } に は 25$ を用いる.

(d) 比較検討ケースは, 侵食防止工無し, 土砂を詰めた ジオテキスタイル袋による離岸堤，および，支柱根タイ プのマングローブ林 $(D=1$; タイ国の人工林に多い密 集度）を設置した計３ケースとする.

ジオテキスタイル製離岸堤の寸法は実例に合わせて，高 さ $2.5 \mathrm{~m} \times$ 幅 $5 \mathrm{~m} \times$ 長さ $50 \mathrm{~m}$ の 1 袋が 1 基の離岸堤とする. 設置する平均水深は最深例に合わせて $1.6 \mathrm{~m}$ 程度とする。 本離岸堤による侵食防止効果は, タイ湾奥部での干満の 潮位差が約 $3 \mathrm{~m}$ であることから, 不透過体の非潜堤と潜 堤の場合について地形変化計算を行い, 各々の継続時間 比（4:1）を重みに用いた平均值から評価する.

この潮位変化を考慮した本離岸堤の侵食防止効果と同程 度の効果を期待出来る非潜堤タイプの透過堤（水深を平 均潮位時に固定）の透過比をCaらの数值モデルから求 めると約0.33であった。この透過比と同程度の消波効果 を期待出来るマングローブ林の幅は，図-5において $D$ $=1$ のグラフで, 透過比 0.33 に対応した $170 \mathrm{~m}(=11.5 \times$ $\sqrt{9.8 \times 1.6} \times 3.7$ ） とする．林の沿岸長は本離岸堤との 比較のため, 不自然であるが $50 \mathrm{~m}$ とた。. 本林の設置 水深は, 林の陸側端の平均水深を $1.5 \mathrm{~m}$ (干満潮位差が 約 $3 \mathrm{~m}$ ゆえ，干潮時にちょうど干上がる水深）とすれば,
沖側端の平均水深は $2.35 \mathrm{~m}$ なる. マングローブ林の水 深が $2 \mathrm{~m}$ 越えることは稀であるが，林陸側の侵食防止 効果をジオテキスタイル製離岸堤のそれと比較するため, 設置水深をこれ以上浅くしない.

これら 3 ケースのCaらの数值モデルによる計算結果 を図-12〜図-14に示寸．これらの図の比較から，マング ローブ林が陸側海域で，ジオテキスタイル製離岸堤と同 程度以上の侵食防止効果を発揮することを確認できた.

\section{4. 主要な結論}

(1) マングローブ林直前面での入射有義波の波高と波長, および，林の密集度と岸沖幅功ら不規則波の透過比を求 められる算定図を作成できた.

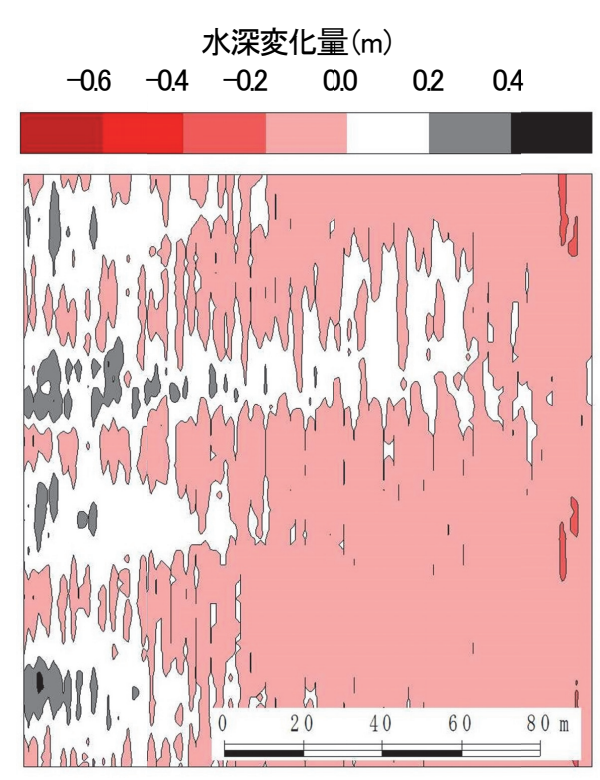

図-12 侵食防止工無しの水深変化計算結果

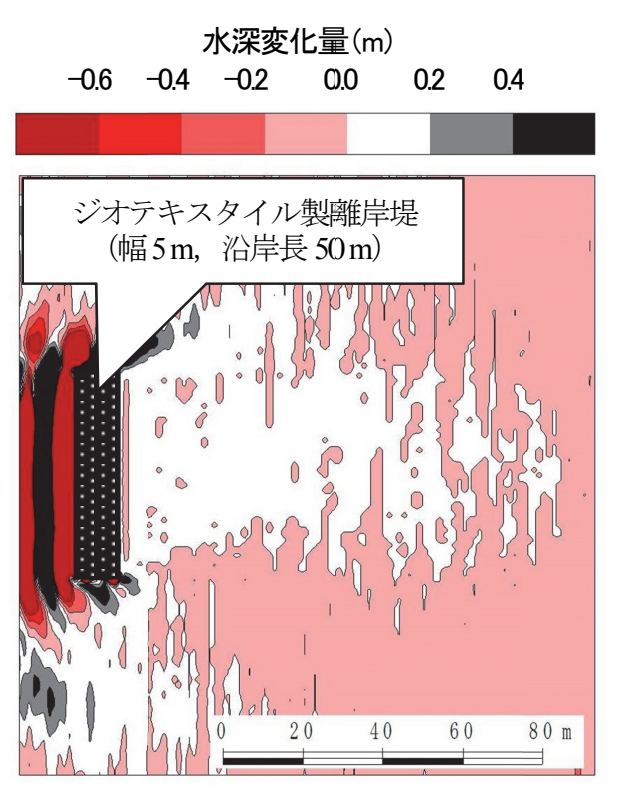

図-13 ジオテキスタイル製離岸堤の水深変化計算結果 


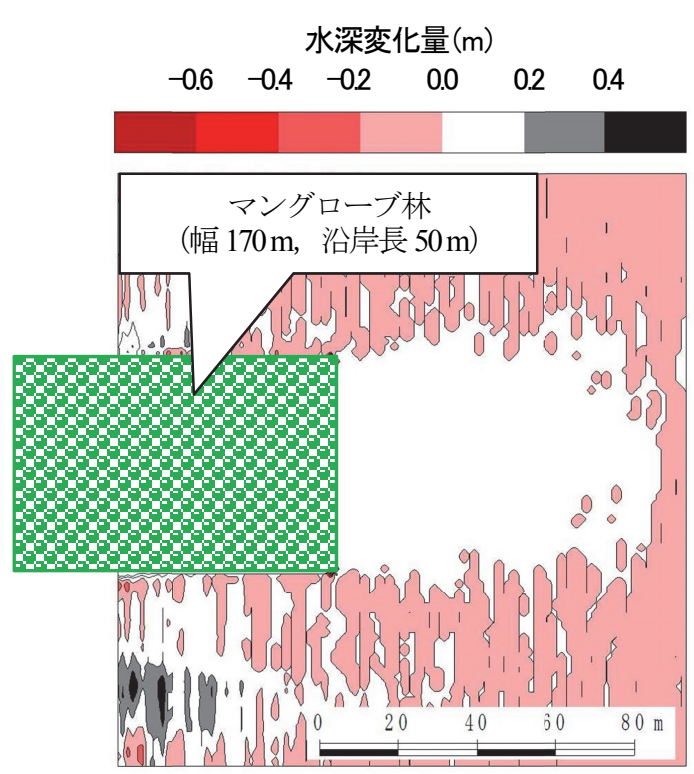

図-14 マングローブ林の水深変化計算結果

(2) $\mathrm{Ca}$ の数值モデルは平面二次元モデルであるため, 通常のPCで簡便に計算可能であり，侵食実験データと の比較から，海岸地形変化について十分な予測精度を有 することを確認できた，そして，典型的なジオテキスタ イル製離岸堤と同程度の侵食防止効果を期待できるマン グローブ林の幅は，地面 $1 \mathrm{~m}^{2}$ 当り 1 本の密集度で， 170 $\mathrm{m}$ とることを $\mathrm{Ca}$ の数值モデルから確認できた.

謝辞 : 本研究は, 東海大学後援会とモンクット王工科大 学の研究助成によって，成し遂げることが出来ました. ここに，記して感謝の意を評します.

\section{参考文献}

1) Rattanarama, P., Nopmueng, A., 山本吉道: シルト質内湾での現 地特性を活かした海岸侵食対策の検討，土木学会論文集
B2 (海岸工学) , Vol.69, No.2, pp.I 716-I 720, 2013.

2) Nopmueng, A., 山本吉道, Rattanarama, P.: タイ国でのマング ローブ林の特徵と海岸侵食防止効果，土木学会論文集 B 3 (海洋開発)，Vol.70, No.2, pp.I_768-I_773, 2014.

3) Bao, T. Q.: Effect of mangrove forest structures on wave attenuation in coastal Vietnam, OCEANOLOGIA, 53 (3), doi: 10.5697/oc.53-3.807, pp.807-818,2011.

4) Brinkman, R. M.: Wave attenuation in mangrove forests: an investigation through field and theoretical studies, pp. $85-109, \mathrm{PhD}$ thesis in James Cook University, 2006.

5) Fatimah, E., Wahab, A. K. A. and Ismail, H.: Numerical modeling approach of an artificial mangrove root system (ArMS) submerged breakwater as wetland habitat protector, COPEDEC VII, Dubai, UAE, Paper No.F-01,pp.1-20, 2008.

6) Kristiyanto, A., Armono, H. D. and Soemarno: Sea Wave Transmission at the Mangrove Forest of Rhizophora Sp, The International Journal of Engineering and Science (IJES), Vol.2, Issue7, ISSN (e): 2319 - 1813 $\operatorname{ISSN}$ (p): 2319-1805, pp.9-17, 2013.

7) Narayan, S.: The Effectiveness of Mangroves in Attenuating Cycloneinduced Waves, pp.42-72, Master thesis in Delft University of Technology, 2009.

8) Mclvor, A., Moller, I., Spencer, T. and Spalding, M.: Reduction of Wind and Swell Waves by Mangroves, Natural Coastal Protection Series ISSN 2050-7941, University of Cambridge, pp.1-27, 2012.

9) Suzuki, T.: Wave Dissipation Over Vegetation Fields, doctral dissertation in Delft University of Technology, ISBN978-94-91211-44-7, 2011.

10) Tuyen, Nguyen Ba. and Hung, Ho Viet: An Experimental Study on Wave ReductionEfficiency of Mangrove Forests, APAC2009, 2009.

11) Bretschneider, C.L. and R. O. Reidl: Modification of wave height due to bottom friction and reflection, B.E.B. Tech. Memo., No.45, 1954.

12) Alongi, M. D.: The Energetics of Mangrove Forests, Springer, 216p., 2009.

13) Ca, V. T., Yamamoto, Y., Tanimoto, K. and Arimura, J.: Simulation on wave dynamics and scouring near coastal structures by a numerical model, Proc. 28th Int. Conf. on Coastal Engrg., ASCE, pp.1817-1829, 2002.

14) 内山雄介 : 干潟のながれと地形変化，ながれ，24，pp.5766, 2005.

(2015.3.18 受付)

\section{EVALUATION METHODS OF THE EFFECT FOR WAVE DISSIPATION AND EROSION PREVENTION BY MANGROVES}

\section{Yoshimichi YAMAMOTO, Puangpet RATTANARAMA and Arjong NOPMUENG}

In Thailand, there are many coasts where serious erosion has occurred owing to the deforestation of mangroves. Coastal structures for preventing the erosion, such as a detached breakwater, are being constructed on many such coasts. However, just reproduction of a mangrove wood is considered to be a natural and perpetual countermeasure. So, from all the kinds of mangroves, as the type of which reproduction of woods is easy and as the type which is expected high wave dissipation effect in 7-8 years, the type which has supporting roots like octopus-legs is chosen, and methods for evaluating the effect of wave dissipation and erosion prevention by this type on the basis of high reliability are proposed. Specifically, experiments on the wave dissipation effect by mangroves are conducted, and a practical diagram for evaluating the wave dissipation ratio is proposed by combining with the data of existing papers. Next, the good reproducibility of the numerical simulation model for predicting coastal topographicall change of $\mathrm{Ca}$ et al. is checked using experimental data on the erosion prevention effect by mangroves. Then, the necessary width of an effective mangrove wood is examined using the numerical simulation model. 